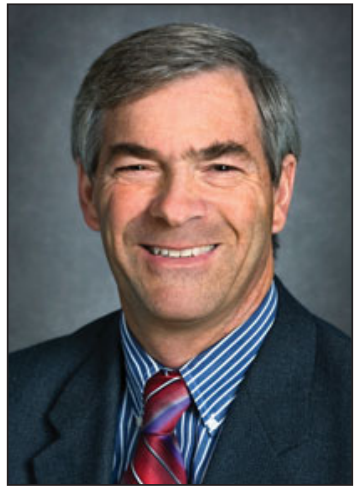

Jim De Yoreo 2011 MRS President

\section{MRS governance documents to be modernized}

Later this year, members of the Materials Research Society will be asked to ratify modifications to the legal documents that define how our Society is governed. In order to set the stage for that vote, I want to briefly describe the motivation behind the change and the nature of the modifications.

Over the last three years, the Board of Directors has made "governance excellence" one of its highest priorities and has pursued its attainment through a major initiative. The outcome has been a set of concrete actions such as codifying certain governing practices and modifying others, developing a formal Policy Manual, instituting an ongoing Board training program, planning leadership training for operating committee chairs and other volunteers, and revamping the strategic planning process to include broad involvement and counsel by the operating committees as well as members at large.

In this vein, as a best practice, a financial and legal review of the Society was authorized in late 2007. One of the recommendations of the legal review was to modernize the MRS governance documents - the Constitution and Bylaws. At the heart of the matter is that the nonprofit laws of the Commonwealth of Pennsylvania, where MRS is incorporated, do not acknowledge the term "Constitution," but refer to the governing documents of nonprofit organizations as "Bylaws." Thus, we were advised to streamline the language in our current "constitution" and to rename it the "MRS Bylaws." To accommodate this recommendation, all information contained in the current Bylaws as well as the information removed from the constitution were to be included in a newly created "Policy Manual."

Beth Stadler, the MRS secretary during this period, was tasked to review the documents and work with legal counsel to make reasonable amendments. In November 2010, she sent the proposed "Bylaws" to the Board and the operating committee chairs. She made it clear - and I confirm it here - that all information in the present Constitution that is currently membervoted will remain so in the new Bylaws, and any issue that is currently Board-voted will remain so, but now as a policy described within the Policy Manual. I want to be clear in stating that these changes in no way alter the privileges or rights of MRS members.

The proposed new Bylaws are undergoing one more review and will be included in a future issue of MRS Bulletin and will be posted on the MRS Web site. A "Rosetta Stone" that details how each point in the proposed Bylaws can be traced directly to an article in the current Constitution will also be presented.

Along with condensing text, the following changes were approved by the Board:

- The current Constitution states that any 100 members can petition to amend the Constitution or to remove an officer or director. This number is very small compared to our current size, and it has been changed over the years to match the size of the 
Society as it grew. At this point, $5 \%$ of the membership is proposed to be required to petition for a member-initiated amendment or removal, with two-thirds of $10 \%$ of the members required (via ballot) for the petition to pass. This number is recommended by Pennsylvania nonprofit law and matches the past numbers in percentage.

- Currently, the Board is authorized to propose amendments to the Constitution. The proposal must be submitted for member vote, but no quorum is defined for the ballot vote. To address this oversight, it is proposed that approval by two-thirds of $5 \%$ of the members eligible to vote be required to pass Board proposed amendments.

- In order to allow future Boards some flexibility with regard to size, it will be proposed that the Board of Directors shall be composed of the officers and 12 to 21 directors, of which up to $25 \%$ may be appointed. The directors who are appointed by the Board pursuant to this Section or Section 4 of this Article need not be members of MRS; all other directors will be elected by the members from among the members. (Vacancies, incapacities, or other inability to serve in an officer or director position shall be filled by appointment by the Board of Directors, for the remainder of the term or until the next annual election, at the discretion of the Board. Such appointments shall not be counted in the $25 \%$ appointment limit.)

- The treasurer position was a three-year term by election up until 2002. At that time, the members voted to change the treasurer to an annual position appointed by the Board, and no term limits were set. We now propose that the treasurer be appointed for an initial one-year term, after which he/she could serve two more years if approved by the Board, and could be reappointed for a second three-year term (similar to directors who may serve up to two consecutive three-year terms).

In addition to the changes in the two governance documents just listed, the legal review identified the need to update the Society's Articles of Incorporation. Specifically, there are two issues that need updating: (1) the address of MRS headquarters, and (2) removing the declaration of the technical interest of the Society from the Articles of Incorporation because it is included in the new Bylaws. These changes require ratification by the membership.

During the annual election in early autumn, the changes that require membership approval will be included on the ballot so that all current members may cast their vote.

I am pleased with the overall progress that has been made to improve the governance functions of MRS thus far, and this modernization of governance documents will be a significant milestone. It will not, however, stop our efforts to continually improve so that we may better serve the membership.

If you have any questions now or after the documents are available for review, I hope that you will feel free to contact me or Sean Hearne, the current MRS secretary (president@, mrs.org; secretary@mrs.org).

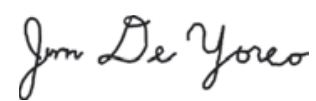

Jim De Yoreo

2011 MRS President 